Z Badań nad Książką i Księgozbiorami Historycznymi 2019. T. specjalny: Dla Niepodległej The Studies into the History of the Book and Book Collections 2019. Special issue: For an Independent Poland

\title{
Recommendations for reading and their educational function in the light of selected Polish guides for librarians and catalogs of books published in the years 1918-1939
}

\begin{abstract}
In the interwar period about 50 different types of guides for librarians and bookselling guides were published in Poland. Many of them contained mainly advices on setting up libraries, organizing them and gathering collections, but both types contained information on selection of books in terms of their educational function. 1) The aim of the research is the presentation of selected guides issued in Poland in 1918-1939, which were addressed to employees of various types of libraries: public, school, parish, home, etc. and their lists of books and recommendations depending on the targeted reader. 2) Materials and methods: selection of guides, comparative method, literature analysis, bibliographic method. 3) Applications are the answers to the following questions: Were the reading recommendations in the analyzed manuals addressed only to the book professionals, as an aid in completing book collections and making reading choices, or to the readers as well? Which educational models were most important, to what extent they referred to the curricula in schools? Whether censorship was taking place (they included titles that should not be read), etc.?
\end{abstract}

Key words: library pedagogy - reading recommendations - guides for librarians - bookselling guides - reading in the first half of the $20^{\text {th }}$ century - educational function of the book.

„Z Badań nad Książką i Księgozbiorami Historycznymi” - Udział zagranicznych recenzentów w ocenie publikacji; Stworzenie anglojęzycznej wersji wydawniczej publikacji; Digitalizacja tomów archiwalnych rocznika w celu zapewnienia otwartego dostępu do nich przez Internet oraz wdrożenie i utrzymanie cyfrowej platformy redakcyjnej - zadanie finansowane w ramach umowy $\mathrm{nr}$ 653/P-DUN/2019 ze środków Ministra Nauki i Szkolnictwa Wyższego przeznaczonych na działalność upowszechniającą naukę. 
When Poland regained its independence in 1918, after more than 100 years of partition, urgent need of organizing structures of the independent state emerged. One of the most urgent task was development of a new education network, to level differences among three annexations. A high percentage of illiterate people made the authorities (including educational ones) aware that without easy access to books education of learned citizens cannot be done. Therefore in the interwar period librarianship was strongly related with pedagogy, firming development of a library pedagogy, in Poland called also as "bibliopedagogy"1. The leading promoters of this direction were (among others) Helena Radlińska (educationist and education promoter), Leon Bykowski (librarian), and Jan Muszkowski (book knowledge expert), to name only the most deserving people in this field. However, development of the structures of Polish libraries was not easy, as there were no librarians with adequate education. Actually, a unified library manual for education of new staff ${ }^{2}$ had not been prepared during the $2^{\text {nd }}$ Republic of Poland, and a few educated book professionals, gathered in large research and public libraries or different associations, were not able to answer the most urgent educational needs of library services. Lack of such a manual affected development of the most easily constructed manuals for the readers ${ }^{3}$, guides in particular, addressed to active librarians, trying to prepare them, although minimally, to run these institutions. The authors of these manuals and guides were distinguished education librarians, who enthusiastically engaged in reconstruction of the Polish libraries after a long period of Poland's partition, aiming at stimulation and increase of reading. The interwar period - according to Anna Nosek - is considered as "a golden period" in activities of educators, teachers, tutors and librarians for reading promotion ${ }^{4}$. Reading guides played an important role in promoting positive attitudes towards a book; which was

1 Originally education functions belonged to school libraries only. However, at the end of the $19^{\text {th }}$ century they were fulfiled also by public libraries. See for example: Ksiażka w pracy oświatowej, Warszawa 1935; L. Bykowski, Ksiązka a pedagogika, "Polska Oświata Pozaszkolna" 1933/1934, Vol. 11, no 8, pp. 254-260; idem: W sprawie pedagogiki bibliotecznej: szkic programowo-dyskusyjny, Warszawa 1938 and other works of this author; H. Radlińska, Zagadnienia czytelnictwa: streszczenie referatu, "Przegląd Biblioteczny" 1932, vol. 6, pp. 133-138; idem: Rola książki i biblioteki, "Rocznik Pedagogiczny" 1924, vol. 2, pp. 63-92.

2 Z. Gaca-Dąbrowska, Bibliotekarstwo II Rzeczypospolitej. Zarys problemów organizacyjnych i badawczych, Warszawa 2007, Nauka, Dydaktyka, Praktyka no 93, pp. 107-109.

3 Such a popular publication was Przewodnik dla korzystajacych z bibljotek oraz spis dziet pomocniczych, by Józef Grycz, Kraków 1925, (b.p.), where one can read in the introduction: "One of library's tasks is cooperation with a school in teaching and general or professional education, thanks to collection and adequate adaptation of required scientific material. Conversely, a scohol should prepare students to rational and effective usage of library collections, training them in library organisation, just like methodology of intellectual work should be taught as well".

4 A. Nosek, "Źródło sity i szczęścia". Pochwaly ksiażki, pożytki plynące z lektury na kartach polskich poradników czytelniczych z dwudziestolecia międzywojennego, "Przegląd Humanistyczny" 2011, vol. 55, no 3, p. 35. 
often discussed in literature ${ }^{5}$. However, the researchers were less interested in the manuals for librarians, in which the role of a book professional in developing reading patterns was underlined, as it was distinctly presented in the interwar period by Jan Augustyniak, director of the Municipal Public Library in Łódź and chair of the Łódź Branch of the Polish Librarians' Union:

A contemporary librarian is a reader's friend, his/her patient and kind teacher, giving freely to everyone and recommending intellectual treasures included in the books. To duly meet librarian's duties, first and foremost a library should be properly organised. Directed to a reader and his/her needs ${ }^{6}$.

The goal of this article is to analyse selected Polish library guides and book catalogues published in the interwar period, in which different reading recommendations are listed, depending on a library type: public (common), school, parish, mobile, and other. The author tries to present educational values, which (according to their authors) should have been promoted among the readers by the librarians or other people associated with a library (e.g. teachers, parents, priests) depending on its type, with particular attention given to children and youth. She also emphasizes differences of reading recommendations depending on a guide publisher, and evaluation of its usefulness for a reader.

\section{A guide as a book type. Description of the analysed collection of guides for librarians}

Approximately 50 different types of library guides were published in the interwar period, although not all of them have been preserved until today. Different reference sources define similarly the term "guide" as a book consisting of recommendations, indications, information concerning selected domain, intended for a selected group of audiences ${ }^{7}$. Edyta Zierkiewicz states that a guide is a type of book:

where firstly a problem is defined, followed by "original" and "author's" solution. [...] however, the readers are not explicitly informed that $[\ldots]$ they will also receive a specific system of values [...], depending on the author's vision ${ }^{8}$.

Encyklopedia książki published in 2017 defined a guide as:

5 Ibidem.

6 J. Augustyniak, Jak zakładać, organizować i prowadzić bibljoteki publiczne w miastach prowincjonalnych. Zarys ogólny, Łódź 1927, p. 14.

7 See for example: Podręczny stownik bibliotekarza, G. Czapnik, Z. Gruszka in collaboration with H. Tadeusiewicz, Warszawa 2011, p. 265; Uniwersalny słownik języka polskiego, ed. by P. Dubisz, vol. 3, Warszawa 2003, p. 383.

8 E. Zierkiewicz, Poradnik jako podręcznik życia. Krótka refleksja na temat historii gatunku, [in:] Podręczniki i poradniki. Konteksty. Dyskursy. Perspektywy, ed. by M. Chomczyńska-Rubacha, Kraków 2011, p. 110. 
Type of an educational book, which main task is to offer practical advices to a reader and help in solving specific problems. Due to its educational and teaching goals, guides are close to manuals, replace them in teaching people without professional education in a selected domain, or their goals is to deepen theoretical knowledge with some practical solutions. [...] Due to their content and goals, they can be directed to specific groups of recipients ${ }^{9}$.

A guide is a type of functional book, therefore employees of different types of libraries were informed this way on values and significance of collected literature, and from which publisher recommended books should be purchased. It was an important organisational problem, as the library staff was exhorted to collect and maintain only "valuable" books in their institutions, not to yield to readers expectations and whims. Augustyniak warned librarians:

the libraries (public in particular) are flowed by the youth from secondary schools, who read mostly books on literary critics or sex (in terms of a scientific section), or asking for fiction with some eroticism (in terms of belles-lettres). This is the plain truth to be known firstly by those who establish new public libraries ${ }^{10}$.

Faustyn Czerwijowski, another author of guides for librarians, stated in the same vein:

Selection of good and useful books for a reader - this is the most important library's task. It requires from a librarian a detailed and critical knowledge of a library collection, as well as knowledge of the readers, in regard of their intellectual development, preparedness, preferences, etc. [...] A librarian equipped with adequate qualities of mind would manage readership and exert his educating influence on the readers, and therefore a library would become a school. [...] One cannot comply reader's request if he/she looks for a worthless book, as these kind of books should not be available in a library, and they cannot be purchased on a reader's request ${ }^{11}$.

The guides fulfilled different functions. Due to the way of presenting topics they were usually divided into instructional or self-help guides. However, one of the most important types were special guides, where those for the librarians belong. Those discussed in this article come from the Ossolineum collection. The author studied a dozen of publications predominantly meeting the criteria mentioned above ${ }^{12}$. As regards publishing and editing aspects, these are mostly brochures of over a dozen pages or books with no more than 100 pages, approximately 50 pages on average, mostly in a small, handy format, published usually on low-quality paper, with no illustrations, including only

9 M. Matwijów, Poradnik, [in:] Encyklopedia książki, ed. by A. Żbikowska-Migoń and M. Skalska-Zlat, Wrocław 2017, p. 415.

10 J. Augustyniak, Jak zakładać, organizować i prowadzić bibljoteki publiczne..., p. 18.

11 F. Czerwijowski, Biblioteki powszechne. Podręcznik dla zakładających i prowadzacych biblioteki, Warszawa 1919, p. 31.

12 Annex: The list of guides for librarians and publishing catalogues published in Poland in the years 1918-1939. 
graphic schema of book indexing, model library cards, descriptions and drawings of library equipment (furniture, catalogues, desks, tables, etc.). They were published (among others) by library and education organisations and associations, such as: Macierz Polska (Mather Poland, an educational society), Towarzystwo Oświaty Ludowej (the Folk Education Society), Towarzystwo Wydawców Książek (the Book Publishers Society), Towarzystwo Akcyjne Artystyczno-Wydawnicze (Artistic and Publishing Joint Stock Company), different unions, including Poradnia Biblioteczna (Library Counselling Services), Związek Bibliotekarzy Polskich (the Polish Librarians Union), Związek Nauczycielstwa Polskiego (the Polish Teachers Union) or Związek Księgarzy Polskich (the Polish Booksellers Union), and bookstores, including the Michat Arct Bookstore in Warsaw or the Gebethner \& Wolff Bookstore. The guides were written (as mentioned above) by distinguished representatives of library and education professions: Helena Radlińska (Orsza), Wanda Dąbrowska, Jadwiga Filipkowska-Szemplińska, Stanisław Lam, Faustyn Czerwijowski, Jan Augustyniak and Jan Muszkowski.

\section{Guides for librarians}

The main task of guides was to recommend adequate literature and to encourage to read books well prepared in both edition and content aspects. The latter often causes discrepancies. Stanisław Lam (1891-1965) - a publisher, publicists, encyclopaedist, critic and literary historian, during the interwar period editor of the "Przegląd Księgarski" (Bookselling Review), in his work O książce wiernej towarzyszce czlowieka (A book as a constant companion of a man) instructed a reader in such a way:

it should be considered not to start reading worthless and empty books. [...] Not to search for works too straightforward or remaining on the same level as we are. These books cannot give us anything back, cannot enlighten us, they do not expand our views. They are easily read, but with no benefit ${ }^{13}$.

Next Lam informs a librarian what are the fiction readers guided by:

Literary fiction is the most popular among the readers. It has many followers, but too few experts. A novel is particularly popular, for its thread, content, simply saying - a tale. It is a light reading, not exerting, and influencing imagination. A reader usually only wants to find out if the lovers got married or parted, what obstacles they had to overcome and if they did. Besides, for many readers there is nothing more interesting in a romance, nothing worth attention or thought, and he/she completely omits author's remarks woven into a course of a story. It should be mentioned that such a way of reading, as well as the books intended for such reading, have no educational value. [...] A novel is worth

13 P. Lam, O książce wiernej towarzyszce życia, Lwów 1917, p. 17. 
reading if it discusses life questions and offers solutions according to writer's views and understanding ${ }^{14}$.

He further continues:

One should reflect on a book read, think about it. [...] A reader has to evaluate whether a book he/she reads meets requirements of morality, general health, whether it contradicts a nation's and society's aspirations. Finally, whether it depicts accurately human nature and the ideas towards which humanity has been always striving. [...] Depending on these one should devote more or less time to different books ${ }^{15}$.

Lam, as Czerwijowski before, encourages to promote reading books concerning love to both a fellow man and God, concerning patriotism or "pervaded with a religious spirit"16, or "with a good spirit and a humorous sense"17, close to reader's views, but also "while evaluating the books read, one should follow neither trends nor publicity" ". They both recommended librarians to collect books of similar value.

Annotated reading lists were prepared for the professionals working in public libraries of educational character, as a help in completing book collections and counselling the readers. Developed for the libraries' needs, they were to fulfil a role of literature guide. One of the authors of such lists was Wanda Dąbrowska (1884-1974), a teacher, librarian, and educationist. She worked in the Common Libraries Society as an instructor. In the years 19291939 she managed the Reading Counselling Services of the Polish Librarians' Union - Warsaw Branch. In the catalogue of her authorship published in 1939 by the Reading Counselling Services, titled Biblioteka gminna (A community library), she underlined that it was developed and published to facilitate the librarians "rational selection of the books, on which social value of the libraries depends in an extraordinary way" $"$. Wherein she particularly emphasised quality of a book collection:

a library's value depends on "quality, not quantity" of the books, and the popular strategy of purchasing the cheapest books - along with a slogan "the more the better" - backfires severely in practice: books of poor editing quality are uneconomic, as they deteriorate quickly, and small brochures - unattractive for a reader - lie idle on the shelves. Well-edited book is twice as valuable: it is durable, encourages reading, and at the same time evokes readers respect for a book and a library ${ }^{20}$.

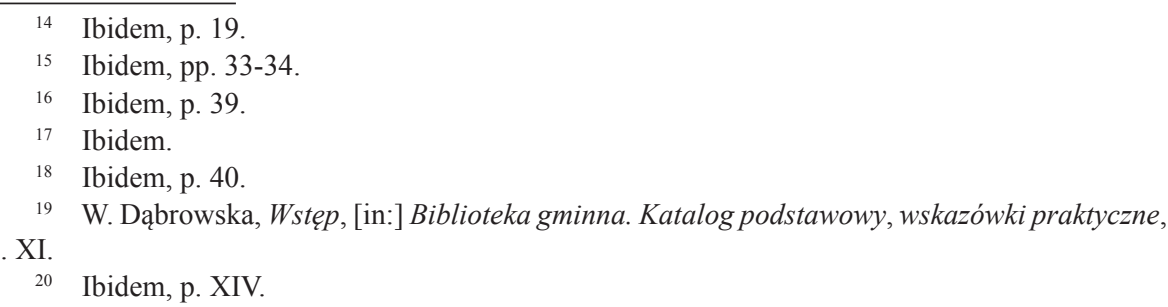


Other authors also underlined the need of rational selection of books, on which social value of a library should depend to a large extend. They often informed librarians that they should transmit patriotic and social values to the readers with a book:

in selection of issues influencing peasant reader's consciousness we limited ourselves to a few but significant ones: as a member of the Polish nation (Chapter I "Our history and our present"); member of the peasant class (Chapter II "A peasant and a village"), member of great human community and a good man (chapters III "To the world", IV "Tribute to a merit" and V "Everlasting values") ${ }^{21}$.

Librarians were also instructed what kind of books should be collected in a library:

poor quality, cheap novels are omitted completely, there is no place for them in public libraries supported with public money. We also avoid works evidently biased, partial, as well as those even artistically outstanding, but atmosphere of which evokes depression, questioning faith in a man and the worthiest values of life. People searching for very easy novels, if we possess too little on an adequate literary level, we refer to the Youth novel section ${ }^{22}$.

Adequate selection of literature was a big challenge for a library worker, joined with a necessity of permanent monitoring Ministry recommended reading lists, as well as different circulars, lists or bibliographies. Therefore in the analysed guides support of a local (community) library commission in a book selection to libraries of different types was recommended, as best oriented in local circumstances. This commission, together with a librarian, should finally decide about purchased literature:

A dedicated committee, consisted of neutral experts - researchers, called in one part from among the society, and in the other, from a non-governmental organisations, could have been an authority with a decisive influence on library's life. A library manager should be a member of such a committee, with equal rights and vote. [...] Adequate quantitative and qualitative selection of books is an effort deciding first and foremost about library's existence and activity. It has been finally accepted that books coming from gifts become a seed of each newly established library. [...] However, it should be remembered that those gifts usually are not valuable, as outdated or incomplete, or they give a book collection a completely random character. Whereas a public library should have a clearly stated educational goal or clear scientific direction of its collection ${ }^{23}$.

Augustyniak clearly explains how he defines an educational goal:

Education of a good reader can be reached twofold: through careful selection of only good books, and through specific library pedagogy in public libraries, realised by young readers and autodidacts. As to the details, I think about a tight control of books gifted to a library,

21 Ibidem, p. XV.

22 Ibidem, p. IX.

23 J. Augustyniak, Jak zakładać, organizować i prowadzić bibljoteki publiczne..., pp. 9-10. 
from among which any fiction or scientific mediocrity should be eliminated. However, if a few from among these books can be perceived as a valuable material to studies into pathological phenomena of cultural life, they should be included to a collection, but offered only to the respected scientists. As for library pedagogy, propaganda of good books should be at the first place. One of the types of such an action is reading aloud of the works carefully selected and making an intellectual set, illustrating a literary argument, or individual books, read in relation to some circumstances (e.g. anniversaries, celebrations, etc.). Books for reading aloud should have outstanding artistic qualities, unknown and passed by an average reader, who even does not guess its internal richness ${ }^{24}$.

A specific role of a librarian refers to development of taste of inexperienced readers. He/she is obliged to direct their reading. An interesting remark is given by the priest Kazimierz Konopka, who writes in the guide Jak urzadzać biblioteki (How to arrange libraries):

A library in rural area, either mobile or a permanent one (i.e. either a reader takes books on place, or a number of books is being sent from one place to another), as almost each smaller library, has one more particular, characteristic feature, that it is being used by people who do not know books. These should be given this book, the one adequate to their intellectual level. A library has to answer community needs, and its manager should collect such books, which are needed for cultural improvement of a reader - either in general or for vocational education ${ }^{25}$.

It is often recommended in the guides, in which bookstores and publishers purchase valuable books. Valuable publishers, according to Konopka, are: the Książnica Atlas in Warsaw, the Ossolineum Publishing in Lvov, the Arct Bookstore in Warsaw, the National Library in Cracow or the Jesuits Publishing in Cracow. Discussing publishing repertoire of individual publishers in the guide, he offers direct value judgments of their publications, e.g.:

St. Wojciech Printing House in Poznań publishes social works, a theatrical library highly appreciated by the associations, a lot of religious and scientific texts and novels. A great advantage of this printing house is that one would not find any "spicy" novels, which cannot be said about such publications of the worthy Gebethner \& Wolff company in Warsaw ${ }^{26}$.

A school library fulfils extremely important role in developing reading views and tastes of young readers. In the interwar period many wise pedagogues and librarians mentioned the need of library in a school. H. Radlińska, in the guide Zadania biblioteki szkolnej (School library's tasks) used also as a manual, underlined this necessity as follows:

A book as a tool is not locked in one room. It happens to be a ubiquitous companion: in classrooms and labs, at homes or even during a walk. Nevertheless, a library is a necessity. Either

\footnotetext{
24 Ibidem, p. 19.

25 K. Konopka, Jak urządzać biblioteki?, Kraków 1925, p. 93.

26 Ibidem, p. 91.
} 
as a place of work with many books, information, and choice, or as a residence of a person who cares for books in a school - a librarian-educationist ${ }^{27}$.

In further parts of this guide she tries to offer the following tips to a librarian, regarding book content and formal values of printings being purchased:

Novels shall be chosen with ideas mind. Masterpieces of literature should be offered in beautiful, attractive editions. A school library should consist of the best works, which should help a man in his development. A librarian should care not so much about quantity as about quality: a harmless book should not be accepted for the reason of larger collection: everything accepted to a library should serve a school life and be "vibrant". [...] Relating reading to interests would be a rescue against "too much and wrong reading", which can be answered only with an activity - excursions, handworks, etc..$^{28}$

Similar to the above author's were opinions of the distinguished pedagogue and librarian Jadwiga Filipkowska-Szemplińska in her guide Organizacja bibliotek szkolnych (Organisation of school libraries). An extensive chapter was focused on discussion of The role of a school library in youth education. The author underlined its role in an intellectual development of a student:

upbringing of a child should arouse passion for books; it should show him/her a potential of satisfying different interests, and introduce him/her into the world of books as faithful friends ${ }^{29}$.

Interestingly, she underlined (as one of the few guide authors) that a pupil may not need librarian's support in a school library, reasoning:

direct access to books, without obligatory librarian's support, develops readers, enabling them contact with different books, which they do not know or do not desire, however which are both interesting and useful. Choice of a book without obligatory librarian's mediation develops child's independence, competence of knowledge of the world of books, and browsing catalogues or bibliographies, which is not a skill possesed by a large group of higher education students nowadays ${ }^{30}$.

Parish libraries - along with public and school ones - played important role in the interwar period Poland in developing readers' tastes and moral patterns, as well as in promotion of catholic values. Priest Marian Fulman in the guide Biblioteki parafialne (Parish libraries) warns against purchase of some publications:

They scrape desperately here and there for opening libraries and reading rooms. A few of them consciously, the others unconsciously litter libraries with plenty of bad or dangerous printings, not agreeing with religion. For example the Centerszwer's Bookstore has a catalogue of self-education library. A mere glance is sufficient to recognize what a danger for faith is hidden down there ${ }^{31}$.

27 H. Radlińska (Orsza), Zadania biblioteki szkolnej, Warszawa 1927, p. 5.

28 Ibidem, pp. 10-11.

29 J. Filipkowska-Szemplińska, Organizacja bibljotek szkolnych, Warszawa 1930, pp. 5-6.

30 Ibidem, p. 19.

31 M. Fulman, Biblioteki parafialne. Ich potrzeba, zaktadanie i prowadzenie, Warszawa 1907, p. 6. 
However, further he underlines the need of preparing adequate lists of books recommended to this type of libraries for people who decided to work in such a libraries without any professional education:

Selection of books to a parish library is not an easy task. Not everything which is printed brings some healthy knowledge. [...] Visiting a book store and picking up a random book, as offered by a bookseller, may be either insidious, harmful, or useless. Book selection should belong to people monitoring national publishing market, with a healthy and firm sense of criticism. [...] Temporary catalogue of books for parish libraries is and will be a plain list, however there are plans and arrangements to an annotated catalogue, where each recommended book will be shortly annotated, if it is required by a library manager. It will be an extremely important instruction for rational management of reading ${ }^{32}$.

Fulman recommended indication of particular books for reading even to "confessors, who can recommend reading an adequate book to various penitents" 33 , and

role and significance of a library depends mostly on its manager and a person lending books. A book goes from librarian's hands to a reader [...], it goes throughout the whole parish, enlightening brains, nourishing hearts, awakening zeal to virtue and work, devotion and fervour, awakening preference to God's matters. It generates yearning for future things, gives understanding of faith, and goal for life ${ }^{34}$.

According to Fulman, a librarian should record how frequently a book is borrowed, because:

it allows for different observations concerning value and usefulness of a book, readers' tastes and preferences, and it also gives an idea of a zeal in intellectual works of the readers ${ }^{35}$.

\section{Catalogues of books offered by publishing houses}

Annotated lists of books offered by large and renowned publishing houses or book stores also played role of guides. They offered indications which texts are directed to particular types of readers, as well as special literal signs accompanying bibliographic descriptions, for different reading groups, i.e. children, youth or adults. Most often particular books were signed in this way, i.e. a Roman numeral I - for beginning readers, and II - for advanced readers. These lists were helpful in particular for the librarians, facilitating literature selection, as no one could read and evaluate each book. While selecting, library workers used willingly such publications: lists, critic and bibliographic recommendations, or catalogues. J. Filipkowska-Szemplińska recommended the librarians

\footnotetext{
32 Ibidem, pp. 18-19.

33 Ibidem, p. 20.

4 Ibidem, pp. 21-22.

35 Ibidem, p. 30.
} 
to browse works prepared by "the Commission for evaluation of books for school youth", active at the Ministry of Religious Affairs and Public Education, as well as the lists published in the "Bibliografia Pedagogiczna" (Pedagogical Bibliography) journal, offering descriptions of publications along with critical analysis of their usefulnesss regarding educational, teaching, scientific, literary, and aesthetic values, as well as those recommended due to their interesting editing features.

The guides in a form of bookstore catalogues were offered by renowned publishing houses. The Gebethner \& Wolff company published even as a special series "Poradnik bibliograficzny dla nauczyciela i wychowawcy" (A bibliographic guide for a teacher and educator), where lists of textbooks for different types of schools, required in following years, were published. As an example one can mention Katalog. Podręczniki szkolne (School texbooks. A catalogue) for the year 1930, discussing textbooks for primary and secondary schools of general education, approved for teaching by the Ministry of Religious Affairs and Public Education. Books in this catalogue were grouped according to particular teaching subjects, and further - according to types of schools. Each title was accompanied by a description. For example the history textbook by Julia Kisielewska $W$ stużbie Ojczyzny. Pogadanki historyczne dla IV oddziatu (In the Motherland's service. Historical talks for the $4^{\text {th }}$ grade; Part I, ed. XVI, 2,80 PLN. Part II, ed. VIII 1929, 2,80 PLN) received the following information:

vivid and colourful organisation, perfect selection of interesting and valuable texts, meaningful for children, make this textbook a favourite pupils book, and provides a number of deserved editions of both parts ${ }^{36}$.

Similar is the case of the textbook by Karol Hławiczka Solfe $\dot{z}$ polski (Polish solfege, Part I, 1,40 PLN, part II, 1,40 PLN, part III, 1,40 PLN), where an interesting annotation can be found:

The "Polish solfege"(song book) introducing adequately selected folk songs, vivid and colourful, of a lasting artistic value, instead of boring rhythm and intonation exercises, enables a teacher to make education more interesting and achieve the best results ${ }^{37}$.

Similar lists of books dedicated to libraries serving young readers were developed under commission of the Library Counselling Services at the Polish Librarians Union. One of such catalogues was Wybór książek dla dzieci i młodzieży (Selection of books for children and youth) edited by W. Dąbrowska. The following comment can be read in additional remarks to this catalogue, point 3:

This catalogue of books is based - as the previous one - on selection, omitting those poor in regard to content or language, as well as those giving rise to educational concern:

36 Gebethner i Wolff, Podręczniki szkolne. Katalog, Łódź 1930, p. 33.

37 Ibidem, p. 55. 
influencing contemptuously on bad instincts, accustoming to cruelty towards any creature, supporting racial or national antagonisms, combating sensitivity to harm and evil. As before, maudlin and deceitful novels are omitted, as well as the books overloaded with boring moralisation $^{38}$.

\section{Point 9 of the Catalogue states:}

Section 9 is designed not for children, but for librarians, teachers, parents and educators, therefore the annotations focus on educational and upbringing elements ${ }^{39}$.

The Library Counselling Services of the Polish Librarians Union, Warsaw Branch offered also information about books for the librarians, developing numerous catalogues dedicated mostly to:

"universal public libraries", i.e. libraries for all users, aiming at and offering either cultural entertainment, or general education. They can also be useful for libraries of any other type, including scientific ones, cultural and educational institutions and organisations, educators, publishers and booksellers, as well as all those interested in the book ${ }^{40}$.

These catalogues were based on the books sent by publishers, but critically evaluated:

more strict selection - in an educational aspect - was applied to fiction for children and youth. The editors usually referred to the opinion of the Commission of Books Evaluation, regarding literary fiction, at the Ministry of Religious Affairs and Public Education, and the Commission of Books Evaluation of the children librarians' circle. Besides sleazy books, omitted were also novels influencing contemptuously on bad instincts, accustoming to cruelty towards any creature, combating sensitivity to harm and evil. From the other hand, also novels overloaded with boring moralisation were omitted ${ }^{41}$.

While preparing short description of a particular books, the following elements were considered:

Potential closer relations between a book and a reader, i.e. consideration of its positive, valuable features, while weak features and defects were omitted. In the section of youth fiction special educational factors were underlined, therefore comments in this section are for the librarians, educators, teachers, not for the young readers ${ }^{42}$.

The publishers themselves took care for adequate level of their books, as being listed in such a catalogue guaranteed profits from sale of large number of copies.

38 Wybór książek dla dzieci i młodzieży. Powieści - opowiadania - poezje, ed. by W. Dąbrowska, Warszawa 1936, p. 4.

39 Ibidem.

40 Przedmowa, [in:] Ksiażka w bibljotece. Katalog informacyjny, ed. by W. Dąbrowska, J.Muszkowski, Warszawa 1934, p. XI.

${ }^{41}$ Ibidem, p. XIV.

42 Ibidem, p. XIX. 


\section{Conclusion}

Library guides in the interwar period played an important role in developing views of book professionals. They also influenced evaluation and selection of literature being purchased to the libraries, as proved by the examples presented above. The librarians completed their collections with regard to educational goals, focused mostly on children and youth, but also on adult readers. These selective bibliographies were information sources concerning publishing repertoire recommended by ministerial institutions and school authorities. They defined their value and usefulness for the readers. They were mostly addressed to the librarians, but used also by teachers, parents and catechists, because similar set of books was recommended to public, parish or school libraries and home collections. Catalogues of books offered by the publishers completed these addressed to the librarians, as they consisted also of annotations concerning valuable content and reading purpose. Analysed guides were developed mostly according to the recommendations of the Ministry of Religious Affairs and Public Education, in consultation with librarians and pedagogues, in particular if they concerned children and youth libraries. In case of adult readers, recommended books were to serve mostly for self-education, and to promote moral and patriotic models. On the other hand, they should not be a source of trivial entertainment or cheap and unhealthy sensation however, this kind of literature were most often sought in libraries by the readers, regrettably for both authors of these guides and book professionals.

Annex:

The list of guides for librarians and publishing catalogues published in Poland in the first half of the $20^{\text {th }}$ century, discussed in this article (in a chronological order of year of publication, and further alphabetically $)^{43}$ :

- Hoffman Karol, Książka i czytanie. Pogadanka społeczna, Drukarnia Warszawskiego Towarzystwa Akcydensowego Artystyczno-Wydawniczego, Warszawa 1902.

- Fulman M[arian], ks., Biblioteki parafialne. Ich potrzeba, zakładanie i prowadzenie. Wydawnictwo "Dziennika Powszechnego", Warszawa 1907.

- Czerwijowski Faustyn, Bibliotekarz. Krótkie wskazówki dla pracujacych w bibliotekach, [Drukarnia K. Kowalewskiego], Warszawa 1912.

43 All guides and catalogues listed here belong to the collection of the Ossolineum Library in Wrocław. 
- Czerwijowski Faustyn, Biblioteki powszechne. Podręcznik dla zakładajacych i prowadzacych biblioteki, Związek Bibliotekarzy Polskich, Warszawa 1919.

- Konopka Kazimierz, ks., Jak urzadzać bibljoteki?, 2 ${ }^{\text {nd }}$, expanded edition, Wydawnictwo Księży Jezuitów, Kraków 1925.

- Lam Stanisław, O ksiażce wiernej towarzyszce człowieka, Macierz Polska, Lwów 1917 (Biblioteka Macierzy Polskiej nr 106).

- Czerwijowski Faustyn, Biblioteki powszechne. Podręcznik dla zakładajacych i prowadzacych biblioteki, Związek Bibliotekarzy Polskich, Warszawa 1919.

- Rodowicz Stanisław, Jak prowadzić moja bibljotekę. Praktyczne wskazówki w zakresie organizowania bibljotek (wg systemu dziesiętnego), "Księgarnia Polska" Towarzystwa Polskiej Macierzy Szkolnej, Warszawa 1921.

- Orsza Helena [Radlińska Helena], Jak prowadzić bibljoteki wędrowne. Wskazówki i przykłady. Towarzystwo Wydawnicze "Ignis", Torun, Warszawa, Siedlce 1922.

- Grycz Józef, Przewodnik dla korzystajacych z bibljotek oraz spis dziet pomocniczych, Wydawnictwo Towarzystwa Szkoły Ludowej, Kraków 1925.

- Augustyniak Jan, Jak zakładać, organizować i prowadzić bibljoteki publiczne w miastach prowincjonalnych. Zarys ogólny, Nakładem Wydawnictwa “Życie Włocławka i okolicy”, Łódź 1927.

- Katalog biblioteki wzorcowej dla dzieci i młodzieży, Nakładem Związku Księgarzy Polskich, Warszawa 1927.

- Radlińska Helena (Orsza), Zadania biblioteki szkolnej, Księgarnia M. Arcta, Warszawa 1927.

- Filipkowska-Szemplińska Jadwiga, Organizacja bibljotek szkolnych, z przedmową H. Radlińskiej, Wydawnictwo Polskiego Towarzystwa Wydawców Książek, Warszawa 1930.

- Gebethner i Wolff, Podręczniki szkolne. Katalog, Łódź 1930. (seria: Poradnik Bibliograficzny Nauczyciela i Wychowawcy I).

- Ksiażka w bibljotece. Katalog informacyjny. Collective work edited by Wanda Dąbrowska, with Jan Muszkowski, Nakładem Polskiego Towarzystwa Wydawców Książek i Związku Księgarzy Polskich, Warszawa 1934. (Poradnia Biblioteczna Warszawskiego Koła ZBP).

- Wybór książek dla dzieci i młodzieży. Powieści - opowiadania - poezje. Collective work edited by Wanda Dąbrowska, Poradnia Biblioteczna Związku Bibliotekarzy Polskich, Warszawa 1936.

- Biblioteka gminna. Katalog podstawowy, wskazówki praktyczne, Collective work edited by Wanda Dąbrowska, Poradnia Biblioteczna Warszawskiego Koła Związku Bibliotekarzy Polskich, Warszawa 1939. 
- Radlińska Helena (Orsza), Biblioteki oświatowe. A copy from Encyklopedia Wychowania, Nakładem "Naszej Księgarni” Spółki Akcyjnej Związku Nauczycielstwa Polskiego, Warszawa 1939.

Translated by Matgorzata Kisilowska

\section{References}

Gaca-Dąbrowska Z., Bibliotekarstwo II Rzeczypospolitej. Zarys problemów organizacyjnych $i$ badawczych, Warszawa 2007.

Matwijów M., Poradnik, [in:] Encyklopedia książki, ed. by A. Żbikowskia-Migoń i M. Skalska-Zlat, Wrocław 2017.

Nosek A., "Źródło sity i szczęścia”. Pochwaty książki, pożytki płynace z lektury na kartach polskich poradników czytelniczych z dwudziestolecia międzywojennego, "Przegląd Humanistyczny" 2011 vol. 55, no 3.

Podręczny słownik bibliotekarza, G. Czapnik, Z. Gruszka, in collaboration with H. Tadeusiewicz, Warszawa 2011.

Uniwersalny słownik języka polskiego, ed. by S. Dubisz, vol. 3, Warszawa 2003.

Zierkiewicz E., Poradnik jako podręcznik życia. Krótka refleksja na temat historii gatunku, [in:] Podręczniki i poradniki. Konteksty. Dyskursy. Perspektywy, ed. by M. Chomczyńska-Rubacha, Kraków 2011. 
